\title{
Pengaruh Modifikasi Media Arang Sekam dan Pemberian Teh Kompos terhadap Pertumbuhan dan Hasil Tanaman Cabai Rawit (Capsicum frutescens L.)
}

\author{
Krisantus Tri Pambudi Raharjo dan Remigius Takaeb ${ }^{\mathrm{b}}$ \\ ${ }^{a}$ Fakultas Pertanian, Universitas Timor, Kefamenanu, TTU - NTT, Indonesia, email: initriraharjaa@gmail.com
}

${ }^{b}$ Fakultas Pertanian, Universitas Timor, Kefamenanu, TTU - NTT, Indonesia, email: remigiustakaeb18@ gmail.com

\section{Article Info}

Article history:

Received 11 Juni 2019

Received in revised form 10 Agustus 2019

Accepted 10 Januari 2020

DOI:

https://doi.org/10.32938/sc.v4i01.733

Keywords:

Arang Sekam

Capsicum frutescens $\mathrm{L}$

Modifikasi Media Tanam

\section{Abstrak}

Arang sekam memiliki peranan penting sebagai media tanam pengganti tanah. Arang sekam bersifat porous, ringan, tidak kotor dan cukup dapat menahan air. Pengaruh arang sekam padi menghasilkan bobot buah dan jumlah buah pertanaman lebih tinggi. Selain itu arang sekam dapat berpengaruh baik terhadap sifat fisik tanah, kimia tanah, dan biologi tanah. Kelebihan arang sekam yaitu dapat menetralkan $\mathrm{pH}$ tanah, yang digunakan dalam jumlah besar, bahkan dalam pertanian organik sumber utama berasal dari arang sekam dan mempertinggi porositas tanah secara langsung meningkatkan ketersediaan air tanah. Kompos teh memiliki beberapa keuntungan dan merupakan produk pupuk alami yang ramah lingkungan, mampu menekan pertumbuhan bakteri patogen yang terdapat di dalam kompos. Disamping sebagai pupuk alami kompos teh juga dapat berfungsi sebagai pestisida alami, karena kompos teh mampu mengembalikan kesuburan tanah secara alami serta meningkatkan daya tahan tanaman terhadap hama dan penyakit. Aplikasi kompos teh selain dapat meningkatkan kandungan nutrisi tanah juga dapat meningkatkan populasi mikroorganisme yang bermanfaat untuk meningkatkan kesuburan tanah. Aplikasi pada daun, dapat menekan perkembangan patogen penyebab penyakit daun. Tujuan penelitian yakni untuk mengetahui pengaruh modifikasi media arang sekam terhadap pertumbuhan dan hasil tanaman cabai rawit serta untuk mengetahui pengaruh teh kompos terhadap pertumbuhan dan hasil tanaman cabai rawit. Penelitian ini telah dilaksanakan di KM 9 Kelurahan Sasi, Kecamatan Kota, Kabupaten Timor Tengah Utara (TTU), Penelitian lapangan mengunakan rancangan acak lengkap (RAL) faktorial $3 \times$ 3 diulang sebanyak 3 kali. Faktor pertama adalah modifikasi media tanam yaitu; tanpa tanah, penutup tanah setengah lingkaran pada permukaan polybag, penutup tanah penuh. Faktor kedua adalah penyemprotan pupuk teh kompos yaitu; tanpa pemberian teh kompos gamal, teh kompos guano. Dengan demikian diperoleh 9 kombinasi perlakuan yang diulang 3 kali sehingga terdapat 27 satuan percobaan. Hasil penelitian menunjukkan bahwa kadar lengas tertinggi dan $\mathrm{pH}$ tanah netral, tinggi tanaman tertinggi, diameter batang terbesar, berat kering tanaman terberat, jumlah buah pertanaman terbanyak, berat buah terberat, dan berat kering tanaman terberat diperoleh dari pemberian teh kompos guano dan penutup tanah penuh.

\section{Pendahuluan}

Cabai rawit (Capsicum frutescens L.) merupakan salah satu tanaman hortikultura dari famili Solanaceae yang tidak saja memiliki nilai ekonomi tinggi, juga karena buahnya yang memiliki kombinasi warna, rasa, dan nilai nutrisi yang lengkap (Kouassi dkk., 2012). Varietas cabai rawit dengan tingkat kepedasan sedang dan tinggi digunakan baik dalam bentuk segar maupun olahan, sedangkan dengan tingkat kepedasan rendah digunakan untuk produksi oleoresin atau bahan pelengkap makanan (Sharma dkk., 2008). Secara umum, buah Cabai rawit mengandung zat gizi antara lain lemak, protein, karbohidrat, kalsium, fosfor, besi, vitamin A, B1, B2, C, dan senyawa alkaloid seperti capsaicin, oleoresin, flavanoid, dan minyak esensial. Ikpeme dkk., (2014) melaporkan bahwa di antara genus cabai, cabai rawit memiliki kandungan protein, abu, dan anthraquinone paling tinggi. Cabai rawit merupakan salah satu komoditas yang dibutuhkan masyarakat sehari-hari. Umumnya masyarakat menyukai rasa pedas dari cabai ini. Bahkan banyak pula yang menjadikan cabai rawit sebagai salah satu pembangkit selera makan. Dengan pertimbangan tersebut, menanam cabai ini tidak ada ruginya bahkan keuntungan yang menggiurkan dapat diraih. Menurut Setiadi, 2002, tanaman cabai berasal dari dari daerah tropik dan subtropik benua Amerika khususnya Colombia, Amerika Selatan, dan terus menyebar ke Amerika Latin. Penyebaran Cabai ke seluruh dunia termasuk negara-negara di Asia, seperti Indonesia dilakukan oleh pedagang Spanyol dan Portugis. Diperkirakan terdapat 20 spesies cabai yang sebagian besar hidup dan berkembang di Benua Amerika, tetapi masyarakat Indonesia umumnya hanya mengenal beberapa jenis saja, yakni cabai besar, cabai keriting, cabai rawit, dan paprika (Harpenas dan Dermawan, 2010). Produksi cabai rawit di Kabupaten Timor Tengah Utara (TTU) dari tahun 20152018 adalah 95 ton, 70 ton, 65 ton dan 60 ton. Badan Pusat Statistik (BPS, 2015). Penurunan produksi cabai rawit disebabkan oleh penggunaan pupuk anorganik yang berlebihan. Hal ini didasarkan pada kenyataan bahwa di wilayah Kabupaten TTU masyarakat petani belum banyak menerapkan tentang penggunaan arang sekam dan pupuk cair atau teh kompos dalam budidaya cabai rawit.

Arang sekam adalah salah satu media tanam yang baik untuk menunjang pertumbuhan tanaman karena sifatnya yang seolite. Selain dapat menyuburkan tanah juga dapat menyimpan unsur hara dalam tanah sehingga tidak mudah tercuci oleh air dan akan mudah dilepaskan ketika dibutuhkan atau diambil oleh akar. Arang sekam sendiri memiliki peranan penting sebagai media tanam pengganti tanah (Anwar, 2018). Arang sekam bersifat porous, ringan, tidak kotor dan cukup dapat menahan air. Penggunaan arang sekam cukup meluas dalam budidaya tanaman hias maupun sayuran (terutama budidaya secara hidroponik). Kompos teh atau pupuk cair organik berguna untuk menyuburkan tanaman. Kompos teh bukan dibuat dari daun teh, melainkan dibuat dari pupuk atau kompos yang berasal dari sampah taman kota atau pasar. Selain menyuburkan, teh kompos dapat digunakan sebagai pestisida organik karena populasi mikrobanya dapat berfungsi sebagai pemberantas hama. Kompos teh yakni ekstrak kompos (kompos yang diekstrak dengan air) akhir-akhir ini mendapat perhatian luas dari para peneliti dan penggiat pertanian organik karena selain menyediakan unsur hara secara langsung pada tanaman dan tanah, juga berfungsi sebagai biokontrol hama dan penyakit tanaman. Pemberian teh kompos juga dapat menambah substansi humus, hormon tumbuh dan enzim serta senyawa-senyawa organik lainnya di dalam tanah (St. Martin, 2015; Pant dkk 2012).Compos tea (CT) adalah ekstrak cair yang berasal dari perendaman kompos (Scheuerell dan Mahaffee, 2002). Aplikasi pupuk organik dapat dilakukan dengan pupuk organik padat maupun cair, seperti teh kompos. Dari uraian di atas maka penelitian bertujuan untuk mengetahui pengaruh modifikasi media arang sekam terhadap pertumbuhan dan hasil tanaman cabai rawit serta untuk mengetahui pengaruh teh kompos terhadap pertumbuhan dan hasil tanaman cabai rawit.

\section{Metode}

Penelitian ini telah dilaksanakan pada bulan Januari tahun 2019 di KM 9 , Kelurahan Sasi, Kecamatan Kota Kefamenanu, Kabupaten TTU. Topografi dataran dengan ketinggian $400 \mathrm{mdpl}$, curah hujan 900-1500 mm per tahun, suhu udara berkisar antar $27^{\circ} \mathrm{C}$ dan $\mathrm{pH}$ tanah netral $(6,5)$. Rancangan yang digunakan dalam penelitian ini adalah Rancangan Acak Lengkap (RAL) $3 \times 3$ yang diulang 3 kali. Faktor Pertama adalah modifikasi media arang sekam padi (T) yang terdiri dari 3 aras perlakuan yaitu: tanpa penutup tanah (T0), penutup tanah setengah lingkaran pada permukaan polybag (T1), penutup tanah penuh permukaan polybag (T2) Faktor kedua adalah pemberian pupuk (P) yang terdiri dari 3 aras perlakuan yaitu: tanpa pupuk (P0), kompos teh daun gamal (P1), kompos teh guano (P2). Kombinasi perlakuan adalah: T0P0, T0P1, T0P2, T1P0, T1P1, T1P2, T2P0, T2P1, T2P2 yang masing-masing diulang 3 kali sehingga terdapat 27 unit penelitian. Parameter yang diamati yakni suhu tanah, suhu udara, kelembaban udara, kadar lengas tanah, $\mathrm{pH}$ tanah, diameter batang, tinggi tanaman, jumlah daun, luas daun, jumlah buah per tanaman, berat buah per tanaman, berat kering tanaman, berat kering akar, berat kering tajuk, indeks panen. Data hasil pengamatan kemudian dianalisa dengan menggunakan sidik ragam (Anova) Rancangan Acak Lengkap (RAL). Rata-rata perlakuan selanjutnya diuji lanjut dengan menggunakan Duncan Multiple Range Test (DMRT) dengan tingkat signifikan $5 \%$ sesuai petunjuk Gomez dan Gomez (2010). Analisa data menggunakan program SAS 9.1

\section{Hasil dan Pembahasan 3.1 Hasil} Suhu Udara

Lingkungan merupakan faktor yang dapat mempengaruhi pertumbuhan tanaman sebagai faktor eksternal dan faktor internalnya yaitu genetika dari tanaman. Keadaan cuaca merupakan faktor eksternal yang meliputi suhu dan kelembaban udara. Tanaman cabai rawit (capsicum frutescens $\mathrm{L}$.) dapat tumbuh dengan baik pada suhu optimum berkisar $30-35^{\circ} \mathrm{C}$ (Tabel 1) pada saat penelitian berlangsung rata-rata suhu udara diatas suhu optimum. Suhu minimum, paling rendah pada bulan Maret yaitu $(21,7)$ suhu udara maksimalsemuanya $\left(42^{\circ} \mathrm{C}\right.$.)

\section{Kelembaban Udara}

Kelembaban udara yang sesuai untuk pertumbuhan tanaman cabai rawit adalah 60-70 \%, pada saat penelitian kelembaban udara diatas $70 \%$ (Tabel 2). Pada saat penelitian berlangsung rata-rata suhu udara diatas suhu optimum. kelembaban minimum, paling rendah pada bulan Januari yaitu (45\%) kelembaban udara maksimum semuanya $(77,75 \%)$ 
Tabel 1. Suhu Udara

\begin{tabular}{cccc}
\hline Bulan & Suhu Maksimal $\left({ }^{\circ} \mathrm{C}\right)$ & Suhu Mimum $\left({ }^{\circ} \mathrm{C}\right)$ & Rerata \\
\hline Januari & 38,8 & 24,3 & $31,55 \mathrm{c}$ \\
Februari & 40,2 & 30,5 & $35,35 \mathrm{a}$ \\
Maret & 46,7 & 21,7 & $34,2 \mathrm{~b}$ \\
April & 45,7 & 25,5 & $35,6 \mathrm{a}$ \\
Rerata & $42,85 \mathrm{a}$ & $25,5 \mathrm{~b}$ & $(-)$ \\
\hline
\end{tabular}

Keterangan: Angka pada baris dan kolom diikuti huruf sama menunjukkan tidak berbeda
pada tingkat nyata $(\alpha) 5 \%$ menurut uji DMRT. (-) tidak terjadi interaksi antar faktor.

Tabel 2. Kelembaban Udara

\begin{tabular}{cccc}
\hline Bulan & Maksimum (\%) & Minimum (\%) & Rerata \\
\hline Januari & 77 & 45 & $61 \mathrm{c}$ \\
Februari & 76 & 57 & $66,5 \mathrm{~b}$ \\
Maret & 78 & 65 & $71,5 \mathrm{a}$ \\
April & 80 & 60 & $70 \mathrm{a}$ \\
Rerata & $77,75 \mathrm{a}$ & $56,75 \mathrm{~b}$ & $(-)$ \\
\hline
\end{tabular}

Keterangan: Angka pada baris dan kolom diikuti huruf sama menunjukkan tidak berbeda pada tingkat nyata ( $\alpha$ ) $5 \%$ menurut uji DMRT. (-) tidak terjadi interaksi antar faktor.

\section{Suhu Tanah}

Hasil sidik ragam (Anova) menunjukkan tidak terjadi interaksi antara perlakuan penyemprotan teh kompos dan pemberian penutup tanah terhadap suhu tanah. Aras perlakuan pemberian penutup tanah berpengaruh tidak nyata terhadap suhu tanah pada waktu pengamatan 14 HST sampai 56 HST namun perlakuan tanpa penutup tanah suhu tanah cenderung lebih tinggi $\left(26,42^{\circ} \mathrm{C}\right)$ dibanding perlakuan pemberian penutup tanah setengah lingkaran permukaan media dan penutup tanah penuh (Tabel 3). Aras perlakuan penyemprotan teh kompos tidak menunjukkan beda nyata terhadap suhu tanah pada waktu pengamatan 14 HST sampai 56 HST namun perlakuan penyemprotan teh kompos gamal cenderung lebih tinggi $\left(26,38^{\circ} \mathrm{C}\right)$ pada pengamatan $14 \mathrm{HST}$ dibanding perlakuan lainnya.

Tabel 3. Suhu Tanah

\begin{tabular}{cccccc}
\hline $\begin{array}{c}\text { Waktu } \\
\text { Pengamatan } \\
\text { (HST) }\end{array}$ & $\begin{array}{c}\text { Bahan Teh } \\
\text { Kompos }\end{array}$ & $\begin{array}{c}\text { Tanpa } \\
\text { Tanah }\end{array}$ & $\begin{array}{c}\text { Penutup } \\
\text { Tanah 1/2 }\end{array}$ & $\begin{array}{c}\text { Penutup } \\
\text { Tanah Penuh }\end{array}$ & \multirow{2}{*}{ Rerata } \\
\hline \multirow{3}{*}{14} & Tanpa & 26,33 & 25,97 & 25,83 & $26,04 \mathrm{a}$ \\
& Gamal & 26,41 & 26,56 & 26,16 & $26,38 \mathrm{a}$ \\
& Guano & 26,52 & 26,02 & 26,02 & $26,18 \mathrm{a}$ \\
\cline { 2 - 5 } & Rerata & $26,42 \mathrm{a}$ & $26,18 \mathrm{a}$ & $26 \mathrm{a}$ & $(-)$ \\
\hline \multirow{3}{*}{28} & Tanpa & 24,41 & 24,81 & 24,01 & $24,41 \mathrm{a}$ \\
& Gamal & 24,63 & 24,84 & 24,65 & $24,71 \mathrm{a}$ \\
& Guano & 25,36 & 24,81 & 24,8 & $24,99 \mathrm{a}$ \\
\cline { 2 - 5 } & Rerata & $24,80 \mathrm{a}$ & $24,82 \mathrm{a}$ & $24,48 \mathrm{a}$ & $(-)$ \\
\hline \multirow{5}{*}{56} & Tanpa & 25,87 & 25,5 & 24,95 & $25,44 \mathrm{a}$ \\
& Gamal & 25,31 & 25,8 & 25,04 & $25,38 \mathrm{a}$ \\
& Guano & 25,22 & 25,13 & 25,34 & $25,23 \mathrm{a}$ \\
\cline { 2 - 5 } & Rerata & $25,47 \mathrm{a}$ & $25,47 \mathrm{a}$ & $25,11 \mathrm{a}$ & $(-)$ \\
\hline
\end{tabular}

Keterangan: Angka pada baris dan kolom diikuti huruf sama menunjukkan tidak berbeda pada tingkat nyata ( $\alpha$ ) $5 \%$ menurut uji DMRT. (-) tidak terjadi interaksi antar faktor.

\section{pH tanah}

Hasil sidik ragam (Anova) menunjukkan tidak terjadi interaksi antara perlakuan penyemprotan teh kompos dan pemberian penutup tanah terhadap parameter pengamatan $\mathrm{pH}$ tanah. Aras perlakuanpenutup tanah berpengaruh tidak nyata terhadap $\mathrm{pH}$ tanah. Namun perlakuan penutup tanah setengah lingkaran permukaan media $\mathrm{pH}$ tanah cenderung lebih netral $(6,62)$ dibanding perlakuan lainya.Sedangkanaraspenyemprotan teh kompos berpengaruh tidak nyata terhadap $\mathrm{pH}$ tanah namun pada Tabel 4 . Perlakuan penyemprotan teh kompos guano $\mathrm{pH}$ tanah cenderung lebih netral $(6,64)$ dibanding perlakuan penyemprotan teh kompos gamal dan tanpa penyemprotan teh kompos.

Tabel 4. pH Tanah

\begin{tabular}{|c|c|c|c|c|c|}
\hline \multirow[b]{2}{*}{$\begin{array}{c}\text { Waktu } \\
\text { Pengamatan } \\
\text { (HST) }\end{array}$} & \multirow[b]{2}{*}{$\begin{array}{c}\text { Bahan Teh } \\
\text { Kompos }\end{array}$} & \multicolumn{3}{|c|}{ Media Tanam } & \multirow[b]{2}{*}{ Rerata } \\
\hline & & Tanpa Tanah & $\begin{array}{l}\text { Penutup } \\
\text { Tanah } 1 / 2\end{array}$ & $\begin{array}{c}\text { Penutup } \\
\text { Tanah } \\
\text { Penuh }\end{array}$ & \\
\hline \multirow{4}{*}{14} & Tanpa & 6,70 & 6,78 & 6,73 & $6,74 \mathrm{a}$ \\
\hline & Gamal & 6,64 & 6,69 & 6,87 & $6,73 \mathrm{a}$ \\
\hline & Guano & 6,75 & 6,67 & 6,84 & $6,75 \mathrm{a}$ \\
\hline & Rerata & $6,7 \mathrm{a}$ & $6,72 \mathrm{a}$ & $6,81 \mathrm{a}$ & $(-)$ \\
\hline \multirow{4}{*}{28} & Tanpa & 6,66 & 6,76 & 6,72 & $6,71 \mathrm{a}$ \\
\hline & Gamal & 6,62 & 6,74 & 6,83 & $6,73 \mathrm{a}$ \\
\hline & Guano & 6,73 & 6,65 & 6,81 & $6,73 \mathrm{a}$ \\
\hline & Rerata & $6,67 \mathrm{a}$ & $6,72 \mathrm{a}$ & $6,79 \mathrm{a}$ & $(-)$ \\
\hline \multirow{4}{*}{56} & Tanpa & 6,66 & 6,63 & 6,67 & $6,65 \mathrm{a}$ \\
\hline & Gamal & 6,65 & 6,60 & 6,65 & $6,63 \mathrm{a}$ \\
\hline & Guano & 6,61 & 6,63 & 6,69 & $6,64 \mathrm{a}$ \\
\hline & Rerata & $6,64 \mathrm{a}$ & $6,62 \mathrm{a}$ & $6,67 \mathrm{a}$ & $(-)$ \\
\hline
\end{tabular}

Keterangan: Angka pada baris dan kolom diikuti huruf sama menunjukkan tidak berbeda

pada tingkat nyata ( $\alpha$ ) 5\% menurut uji DMRT. (-) tidak terjadi interaksi antar faktor.

\section{Kadar Lengas Tanah}

Hasil sidik ragam (Anova) menunjukkan tidak terjadi interaksi antar perlakuan pemberian teh kompos dan penutupan tanah pada parameter pengamatan kadar lengas tanah terhadap cabai rawit. Aras perlakuan penutup tanah berpengaruh tidak nyata terhadap kadar lengas tanah. Namun perlakuan penutup tanah setengah lingkaran permukaan media terhadap kadar lengas tanah cenderung lebih tinggi $(34,04)$ dibanding perlakuan lainya pada akhir pengamatan. Sedangkan aras perlakuan penyemprotan teh kompos berpengaruh nyata terhadap kadar lengas tanah pada waktu pengamatan 14 dan 28 HST sedangkan pada akhir pengamatan tidak berbeda nyata (Tabel 5.)

Tabel 5. Kadar Lengas Tanah

\begin{tabular}{|c|c|c|c|c|c|}
\hline \multirow{2}{*}{$\begin{array}{c}\text { Waktu } \\
\text { Pengamatan } \\
\text { (HST) }\end{array}$} & \multirow[b]{2}{*}{$\begin{array}{c}\text { Bahan Teh } \\
\text { Kompos }\end{array}$} & \multicolumn{3}{|c|}{ Media Tanam } & \multirow[b]{2}{*}{ Rerata } \\
\hline & & Tanpa Tanah & $\begin{array}{l}\text { Penutup } \\
\text { Tanah } 1 / 2\end{array}$ & $\begin{array}{c}\text { Penutup } \\
\text { Tanah Penuh }\end{array}$ & \\
\hline \multirow{4}{*}{14} & Tanpa & 25,72 & 34,31 & 47,79 & $35,94 \mathrm{~b}$ \\
\hline & Gamal & 55,99 & 46,94 & 45,29 & $49,41 \mathrm{a}$ \\
\hline & Guano & 41,71 & 46,71 & 44,00 & $44,14 \mathrm{a}$ \\
\hline & Rerata & $41,14 \mathrm{a}$ & $42,65 \mathrm{a}$ & $45,70 \mathrm{a}$ & $(-)$ \\
\hline \multirow{4}{*}{28} & Tanpa & 35,99 & 27,35 & 25,99 & $29,78 \mathrm{~b}$ \\
\hline & Gamal & 18,29 & 19,85 & 13,94 & $17,36 \mathrm{~b}$ \\
\hline & Guano & 21,46 & 25,42 & 28,05 & $24,97 \mathrm{a}$ \\
\hline & Rerata & $25,25 \mathrm{a}$ & $24,21 \mathrm{a}$ & $22,66 \mathrm{a}$ & $(-)$ \\
\hline \multirow{4}{*}{56} & Tanpa & 33,13 & 39,16 & 34,11 & $35,47 \mathrm{a}$ \\
\hline & Gamal & 36,20 & 32,31 & 29,13 & $32,55 \mathrm{a}$ \\
\hline & Guano & 30,27 & 30,67 & 33,28 & $31,40 \mathrm{a}$ \\
\hline & Rerata & $33,20 \mathrm{a}$ & $34,04 \mathrm{a}$ & $32,17 \mathrm{a}$ & $(-)$ \\
\hline
\end{tabular}

Keterangan: Angka pada baris dan kolom diikuti huruf sama menunjukkan tidak berbeda pada tingkat nyata $(\alpha) 5 \%$ menurut uji DMRT. (-) tidak terjadi interaksi antar faktor.

\section{Tinggi Tanaman}

Hasil sidik ragam (Anova) menunjukkan tidak terjadi interaksi antara perlakuan penyemprotan teh kompos dan pemberian penutup tanah terhadap parameter pengamatan tinggi tanaman. Aras perlakuan pemberian penutup tanah menunjukan tidak beda nyata terhadap tinggi tanaman pada waktu pengamatan 14 HST sampai 56 HST namun perlakuan tanpa penutup tanah, cenderung menghasilkan tinggi tanaman lebih tinggi $(53,77 \mathrm{~cm})$ dibanding perlakuan pemberian penutup. Aras perlakuan penyemprotan berpengaruh nyata terhadap tinggi tanaman pada waktu pengamatan 28 HST sampai 56 HST tetapi pada waktu pengamatan 14 HST tidak berbeda nyata (Tabel 6). Perlakuan penyemprotan teh kompos guano, tinggi tanaman cenderung lebih tinggi $(54,88$ $\mathrm{cm}$ ) dibanding perlakuan penyemprotan teh kompos gamal dan tanpa penyemprotan teh kompos

\section{Tabel 6. Tinggi Tanaman}

\begin{tabular}{|c|c|c|c|c|c|}
\hline \multirow[b]{2}{*}{$\begin{array}{c}\text { Waktu } \\
\text { Pengamatan } \\
\text { ( HST) }\end{array}$} & \multirow[b]{2}{*}{$\begin{array}{c}\text { Bahan Teh } \\
\text { Kompos }\end{array}$} & \multicolumn{3}{|c|}{ Media Tanam } & \multirow[b]{2}{*}{ Rerata } \\
\hline & & $\begin{array}{l}\text { Tanpa } \\
\text { Tanah }\end{array}$ & $\begin{array}{l}\text { Penutup } \\
\text { Tanah 1/2 }\end{array}$ & $\begin{array}{c}\text { Penutup } \\
\text { Tanah } \\
\text { Penuh }\end{array}$ & \\
\hline \multirow{4}{*}{14} & Tanpa & 23,00 & 24,00 & 21 & $22,66 \mathrm{a}$ \\
\hline & Gamal & 24,00 & 24,66 & 25 & $24,55 \mathrm{a}$ \\
\hline & Guano & 25,00 & 25,33 & 24,15 & $24,83 \mathrm{a}$ \\
\hline & Rerata & $24,00 \mathrm{a}$ & $24,66 \mathrm{a}$ & $23,38 \mathrm{a}$ & $(-)$ \\
\hline \multirow{4}{*}{28} & Tanpa & 33,66 & 35,00 & 32,66 & $33,77 \mathrm{~b}$ \\
\hline & Gamal & 39,00 & 40,00 & 40,00 & 39,66 a \\
\hline & Guano & 41,00 & 41,00 & 45,00 & $42,33 \mathrm{a}$ \\
\hline & Rerata & $37,88 \mathrm{a}$ & $38,66 \mathrm{a}$ & $39,22 \mathrm{a}$ & $(-)$ \\
\hline \multirow{4}{*}{56} & Tanpa & 57,00 & 47,33 & 46,66 & $50,33 \mathrm{~b}$ \\
\hline & Gamal & 51,00 & 51,00 & 53,00 & $51,66 \mathrm{a}$ \\
\hline & Guano & 53,33 & 54,33 & 57,00 & $54,88 \mathrm{a}$ \\
\hline & Rerata & $53,77 \mathrm{a}$ & $50,88 \mathrm{a}$ & $52,22 \mathrm{a}$ & $(-)$ \\
\hline
\end{tabular}

Keterangan: Angka pada baris dan kolom diikuti huruf sama menunjukkan tidak berbeda pada tingkat nyata ( $\alpha$ ) 5\% menurut uji DMRT. (-) tidak terjadi interaksi antar faktor.

\section{Diameter Batang}

Hasil sidik ragam (Anova) menunjukkan tidak terjadi interaksi antara perlakuan penyemprotan teh kompos dan penutup tanah terhadap parameter pengamatan diameter batang. Aras perlakuan pemberian penutup tanah berpengaruh tidak nyata terhadap diameter batang pada waktu pengamatan 56 HST sedangkan pada saat pengamatan 14 HST dan 28 HST berbeda nyata. Perlakuan pemberian penutupan tanah penuh cenderung diameter batang lebih besar $(0,48)$ dibanding tanpa perlakuan pemberian penutup tanah (Tabel 7 ). Penyemprotan teh kompos berpengaruh tidak nyata terhadap diameter batang pada waktu pengamatan 14 HST sampai 56 HST namun perlakuan penyemprotan teh kompos guano, diameter batang cenderung lebih besar $(0,57$ $\mathrm{cm}$ ) dibanding perlakuan penyemprotan teh kompos gamal dan tanpa pemberian teh kompos. 
Tabel 7. Diameter Batang

\begin{tabular}{|c|c|c|c|c|c|}
\hline \multirow[b]{2}{*}{$\begin{array}{c}\text { Waktu } \\
\text { Pengamatan } \\
\text { (HST) }\end{array}$} & \multirow[b]{2}{*}{$\begin{array}{c}\text { Bahan Teh } \\
\text { Kompos }\end{array}$} & \multicolumn{3}{|c|}{ Media Tanam } & \multirow[b]{2}{*}{ Rerata } \\
\hline & & $\begin{array}{l}\text { Tanpa } \\
\text { Tanah }\end{array}$ & $\begin{array}{l}\text { Penutup } \\
\text { Tanah 1/2 }\end{array}$ & $\begin{array}{c}\text { Penutup } \\
\text { Tanah } \\
\text { Penuh }\end{array}$ & \\
\hline \multirow{4}{*}{14} & Tanpa & 0,30 & 0,24 & 0,25 & $0,26 \mathrm{~b}$ \\
\hline & Gamal & 0,43 & 0,36 & 0,35 & $0,38 \mathrm{a}$ \\
\hline & Guano & 0,50 & 0,41 & 0,40 & $0,43 \mathrm{a}$ \\
\hline & Rerata & $0,41 \mathrm{a}$ & $0,33 \mathrm{~b}$ & $0,33 \mathrm{~b}$ & $(-)$ \\
\hline \multirow{4}{*}{28} & Tanpa & 0,35 & 0,29 & 0,3 & $0,31 \mathrm{~b}$ \\
\hline & Gamal & 0,48 & 0,43 & 0,41 & $0,44 \mathrm{a}$ \\
\hline & Guano & 0,53 & 0,50 & 0,49 & $0,51 \mathrm{a}$ \\
\hline & Rerata & $0,45 \mathrm{a}$ & $0,40 \mathrm{~b}$ & $0,40 \mathrm{~b}$ & $(-)$ \\
\hline \multirow{4}{*}{56} & Tanpa & 0,44 & 0,37 & 0,39 & $0,40 \mathrm{~b}$ \\
\hline & Gamal & 0,56 & 0,51 & 0,5 & $0,52 \mathrm{a}$ \\
\hline & Guano & 0,60 & 0,56 & 0,56 & $0,57 \mathrm{a}$ \\
\hline & Rerata & $0,53 \mathrm{a}$ & $0,48 \mathrm{a}$ & $0,48 \mathrm{a}$ & $(-)$ \\
\hline
\end{tabular}

Keterangan: Angka pada baris dan kolom diikuti huruf sama menunjukkan tidak berbed pada tingkat nyata ( $\alpha$ ) $5 \%$ menurut uji DMRT. (-) tidak terjadi interaksi antar faktor.

\section{Jumlah Daun}

Hasil sidik ragam (Anova) menunjukkan tidak terjadi interaksi antara perlakuan penyemprotan teh kompos dan penutup tanah terhadap parameter pengamatan jumlah daun. Aras perlakuan pemberian penutup tanah berpengaruh tidak nyata terhadap jumlah daun pertanaman namun perlakuan pemberian penutup tanah penuh jumlah daun pertanaman cenderung lebih banyak $(67,66)$ dibanding perlakuan tanpa penutup tanah (Tabel 8). Aras perlakuan penyemprotan teh kompos berpengaruh nyata terhadap jumlah daun pada waktu pengamatan 14 HST sampai 56 HST namun perlakuan penyemprotan teh kompos guano jumlah daun cenderung lebih banyak $(75,33$ $\mathrm{cm}$ ) dibanding perlakuan penyemprotan teh kompos gamal dan tanpa penyemprotan teh kompos.

\begin{tabular}{|c|c|c|c|c|c|}
\hline \multirow{2}{*}{$\begin{array}{c}\text { Waktu } \\
\text { Pengamatan } \\
\text { ( HST) }\end{array}$} & \multirow{2}{*}{$\begin{array}{c}\text { Bahan } \\
\text { Teh } \\
\text { Kompos }\end{array}$} & \multicolumn{3}{|c|}{ Media Tanam } & \multirow[b]{2}{*}{ Rerata } \\
\hline & & $\begin{array}{l}\text { Tanpa } \\
\text { Tanah }\end{array}$ & $\begin{array}{l}\text { Penutup } \\
\text { Tanah } 1 / 2\end{array}$ & $\begin{array}{l}\text { Penutup Tanah } \\
\text { Penuh }\end{array}$ & \\
\hline \multirow{4}{*}{14} & Tanpa & 10,66 & 14,33 & 13,00 & $12,66 \mathrm{~b}$ \\
\hline & Gamal & 15,00 & 16,33 & 20,66 & $17,33 \mathrm{a}$ \\
\hline & Guano & 18,33 & 21,33 & 32,00 & $23,88 \mathrm{a}$ \\
\hline & Rerata & $14,66 \mathrm{a}$ & $17,33 \mathrm{a}$ & $21,88 \mathrm{a}$ & $(-)$ \\
\hline \multirow{4}{*}{28} & Tanpa & 32,66 & 32,66 & 35,00 & $33,44 \mathrm{~b}$ \\
\hline & Gamal & 52,00 & 47,00 & 48,00 & $49,00 \mathrm{~b}$ \\
\hline & Guano & 54,00 & 51,00 & 55,00 & $53,33 \mathrm{a}$ \\
\hline & Rerata & $46,22 \mathrm{a}$ & $43,55 \mathrm{a}$ & $46 \mathrm{a}$ & $(-)$ \\
\hline \multirow{4}{*}{56} & Tanpa & 55,00 & 57,33 & 56,00 & $56,11 b$ \\
\hline & Gamal & 71,00 & 67,66 & 69,66 & $69,44 \mathrm{~b}$ \\
\hline & Guano & 75,33 & 73,33 & 77,33 & $75,33 \mathrm{a}$ \\
\hline & Rerata & $67,11 \mathrm{a}$ & $66,11 \mathrm{a}$ & $67,66 \mathrm{a}$ & $(-)$ \\
\hline
\end{tabular}

Keterangan: Angka pada baris dan kolom diikuti huruf sama menunjukkan tidak berbeda pada tingkat nyata ( $\alpha$ ) $5 \%$ menurut uji DMRT. (-) tidak terjadi interaksi antar faktor.

\section{Luas Daun}

Hasil sidik ragam (Anova) menunjukkan tidak terjadi interaksi antara perlakuan penyemprotan teh kompos dan pemberian penutup tanah terhadap parameter pengamatan luas daun. Aras perlakuan pemberian penutup tanah juga berpengaruh tidak nyata terhadap luas daun pada saat pengamatan namun tanpa perlakuan pemberian penutup tanah penuh daun cenderung lebih luas $(580,27$ $\mathrm{cm}$ ) dibanding perlakuan tanpa pemberian penutup tanah (Tabel 9). Aras perlakuan pemberian teh kompos berpengaruh nyata terhadap luas daun pada waktu pengamatan dengan perlakuan penyemprotan teh kompos guano cenderung daun lebih luas $(619,71 \mathrm{~cm})$ dibanding perlakuan penyemprotan teh kompos gamal dan tanpa penyemprotan teh kompos.

Tabel 9. Luas Daun

\begin{tabular}{|c|c|c|c|c|}
\hline \multirow[b]{2}{*}{$\begin{array}{c}\text { Bahan Teh } \\
\text { Kompos }\end{array}$} & \multicolumn{3}{|c|}{ Medi Tanam } & \multirow[b]{2}{*}{ Rerata } \\
\hline & Tanpa Tanah & $\begin{array}{l}\text { Penutup } \\
\text { Tanah } 1 / 2\end{array}$ & $\begin{array}{c}\text { Penutup Tanah } \\
\text { Penuh }\end{array}$ & \\
\hline Tanpa & 179,42 & 331,34 & 466,25 & $325,67 \mathrm{~b}$ \\
\hline Gamal & 579,30 & 636,72 & 640,59 & $618,87 \mathrm{a}$ \\
\hline Guano & 620,09 & 605,08 & 633,96 & $619,71 \mathrm{a}$ \\
\hline Rerata & $459,60 \mathrm{a}$ & $524,38 \mathrm{a}$ & $580,27 \mathrm{a}$ & $(-)$ \\
\hline
\end{tabular}

Keterangan: Angka pada baris dan kolom diikuti huruf sama menunjukkan tidak berbeda pada tingkat nyata ( $\alpha$ ) $5 \%$ menurut uji DMRT. (-) tidak terjadi interaksi antar faktor.

\section{Berat Kering Akar}

Hasil sidik ragam (Anova) menunjukkan tidak terjadi interaksi antara perlakuan penyemprotan teh kompos dan pemberian penutup tanah terhadap parameter pengamatan berat berat kering akar. Aras perlakuan pemberian penutup tanah juga berpengaruh nyata terhadap berat kering akar namun perlakuan tanpa pemberian penutup tanah penuh menghasilkan berat kering akar cenderung lebih berat $(0,32 \mathrm{~g})$ dibanding perlakuan pemberian penutup tanah (Tabel 10). Aras perlakuan penyemprotan teh kompos berpengaruh nyata terhadap berat kering akar namun perlakuan penyemprotan teh kompos gamal menghasilkan berat kering akar yang cenderung lebih berat $(0,32 \mathrm{~g})$ dibanding perlakuan penyemprotan teh kompos gamal dan tanpa penyemprotan teh kompos.

Tabel 10. Berat Kering Akar

\begin{tabular}{ccccc}
\hline \multirow{2}{*}{$\begin{array}{c}\text { Bahan Teh } \\
\text { Kompos }\end{array}$} & $\begin{array}{c}\text { Tanpa } \\
\text { Tanah }\end{array}$ & $\begin{array}{c}\text { Penutup Tanah } \\
1 / 2\end{array}$ & $\begin{array}{c}\text { Penutup } \\
\text { Tanah Penuh }\end{array}$ & Rerata \\
\hline Tanpa & 0,37 & 0,28 & 0,31 & $0,32 \mathrm{a}$ \\
Gamal & 0,27 & 0,24 & 0,25 & $0,25 \mathrm{~b}$ \\
Guano & 0,31 & 0,28 & 0,35 & $0,31 \mathrm{a}$ \\
\hline Rerata & $0,32 \mathrm{a}$ & $0,26 \mathrm{~b}$ & $0,30 \mathrm{a}$ & $(-)$ \\
\hline Keterangan: & Angka pada baris dan kolom diikuti huruf sama menunjukkan tidak berbeda
\end{tabular}
pada tingkat nyata ( $\alpha$ ) 5\% menurut uji DMRT. (-) tidak terjadi interaksi antar faktor.

\section{Berat Kering Tajuk}

Hasil sidik ragam (Anova) menunjukkan tidak terjadi interaksi antara perlakuan penyemprotan teh kompos dan pemberian penutup tanah terhadap parameter pengamatan berat kering tajuk. Aras perlakuan pemberian penutup tanah berpengaruh tidak nyata terhadap berat kering tajuk namun perlakuan pemberian tanah penuh berat kering tajuk cenderung lebih berat $(7 \mathrm{~g})$ dibanding perlakuan pemberian penutup tanah setengah lingkaran permukaan media dan tanpa pemberian penutup tanah (Tabel 11). Aras penelitian penyemprotan teh kompos berpengaruh tidak nyata terhadap berat kering tajuk namun perlakuan penyemprotan teh kompos gamal berat kering tajuk cenderung lebih berat $(6,74$ g) dibanding perlakuan penyemprotan teh kompos guano dan tanpa penyemprotan teh kompos.

\section{Tabel 11. Berat Kering Tajuk}

\begin{tabular}{ccccc}
\hline $\begin{array}{c}\text { Bahan Teh } \\
\text { Kompos }\end{array}$ & Tanpa Tanah & $\begin{array}{c}\text { Penutup } \\
\text { Tanah } 1 / 2\end{array}$ & $\begin{array}{c}\text { Penutup Tanah } \\
\text { Penuh }\end{array}$ & Rerata \\
\cline { 2 - 4 } & 5,6 & 6,1 & 6,93 & $6,21 \mathrm{a}$ \\
Tanpa & 7,1 & 6,46 & 6,66 & $6,74 \mathrm{a}$ \\
Gamal & 6,3 & 6,26 & 7,4 & $6,65 \mathrm{a}$ \\
Guano & $6,33 \mathrm{a}$ & $6,27 \mathrm{a}$ & $7,00 \mathrm{a}$ & $(-)$ \\
\hline Rerata &
\end{tabular}

Keterangan: Angka pada baris dan kolom diikuti huruf sama menunjukkan tidak berbeda pada tingkat nyata ( $\alpha$ ) 5\% menurut uji DMRT. (-) tidak terjadi interaksi antar faktor.

\section{Berat Kering Tanaman}

Hasil sidik ragam (Anova) menunjukkan tidak terjadi interaksi antara perlakuan penyemprotan teh kompos dan pemberian penutup tanah terhadap parameter pengamatan berat kering tanaman. Aras perlakuan pemberian penutup tanah juga berpengaruh tidak nyata terhadap berat kering tanaman namun perlakuan pemberian penutup tanah penuh berat kering tanaman cenderung lebih berat $(17,85 \mathrm{~g})$ dibanding perlakuan tanpa pemberian penutup tanah (Tabel 12). Aras perlakuan pemberian teh kompos berpengaruh tidak nyata terhadap berat kering tanaman namun perlakuan penyemprotan teh kompos gamal berat kering tanaman cenderung lebih berat $(17,80 \mathrm{~g})$ dibanding perlakuan penyemprotan teh kompos guano dan tanpa penyemprotan teh kompos.

\section{Tabel 12. Berat Kering Tanaman}

\begin{tabular}{ccccc}
\hline \multirow{2}{*}{$\begin{array}{c}\text { Bahan Teh } \\
\text { Kompos }\end{array}$} & Tanpa Tanah & $\begin{array}{c}\text { Penutup } \\
\text { Tanah 1/2 }\end{array}$ & $\begin{array}{c}\text { Penutup Tanah } \\
\text { Penuh }\end{array}$ & Rerata \\
\cline { 2 - 4 } & 15,43 & 17,66 & 18,33 & $17,14 \mathrm{a}$ \\
Tanpa & 18,29 & 17,66 & 17,45 & $17,80 \mathrm{a}$ \\
Gamal & 17,17 & 17,56 & 17,78 & $17,50 \mathrm{a}$ \\
Guano & $16,96 \mathrm{a}$ & $17,63 \mathrm{a}$ & $17,85 \mathrm{a}$ & $(-)$ \\
\hline Rerata & Keterangan: Angka pada baris dan kolom diikuti huruf sama menunjukkan tidak berbeda
\end{tabular}

Keterangan: Angka pada baris dan kolom diikuti huruf sama menunjukkan tidak berbed pada tingkat nyata $(\alpha) 5 \%$ menurut uji DMRT. (-) tidak terjadi interaksi antar faktor.

\section{Jumlah Buah Per Tanaman}

Hasil sidik ragam (Anova) menunjukkan tidak terjadi interaksi antara perlakuan penyemprotan teh kompos dan pemberian penutup tanah terhadap parameter pengamatan jumlah buah pertanaman. Aras perlakuan pemberian penutup tanah berpengaruh nyata terhadap jumlah buah pertanaman dari awal panen sampai panen terakhir dengan perlakuan pemberian penutup tanah penuh menghasilkan jumlah buah pertanaman cenderung lebih banyak $(7,66)$ pada panen pertanama begitu pun panen kedua $(13,77)$ panen ketiga juga penutup tanah penuh cenderung lebih banyak $(20,44)$ dan panen keempat pemberian penutup tanah penuh cenderung lebih banyak $(13,55)$ dibanding aras perlakuan pemberian penutup tanah setengah lingkaran permukaan media dan tanpa penutup tanah (Tabel 13). Aras perlakuan penyemprotan teh kompos berpengaruh nyata terhadap jumlah buah pertanaman dari awal panen sampai akhir panen dengan perlakuan pemberian teh kompos gamal menghasilkan jumlah buah pertanaman cenderung lebih banyak $(8,55)$ pada panen pertama yang tidak berbeda nyata dengan teh kompos guano, panen kedua penyemprotan teh kompos guano cenderung lebih banyak (14) yang tidak berbeda nyata dengan teh kompos gamal, pada panen ketiga penyemprotan teh 
kompos gamal cenderung lebih banyak $(22,33)$ yang tidak berbeda nyata dengan teh guano, dan pada panen keempat penyemprotan teh kompos guano cenderung lebih banyak $(13,77)$ yang tidak berbeda nyata denga naras perlakuan tehkompos guano.

\begin{tabular}{|c|c|c|c|c|c|}
\hline \multirow[b]{2}{*}{ Waktu Panen } & \multirow[b]{2}{*}{$\begin{array}{c}\text { Penyemprotan } \\
\text { Teh Kompos }\end{array}$} & \multicolumn{3}{|c|}{ Media Tanam } & \multirow[b]{2}{*}{ Rerata } \\
\hline & & Tanpa & $\begin{array}{l}\text { Penutup } \\
\text { Tanah1/2 }\end{array}$ & $\begin{array}{l}\text { Penutup } \\
\text { Tanah } \\
\text { Penuh }\end{array}$ & \\
\hline \multirow{4}{*}{1} & Tanpa & 3,33 & 3,00 & 4,00 & $3,44 \mathrm{~b}$ \\
\hline & Gamal & 8,00 & 7,33 & 10,33 & $8,55 \mathrm{a}$ \\
\hline & Guano & 7,33 & 6,00 & 8,66 & $7,33 \mathrm{a}$ \\
\hline & Rerata & $6,22 \mathrm{a}$ & $5,44 \mathrm{~b}$ & $7,66 \mathrm{a}$ & $(-)$ \\
\hline \multirow{4}{*}{2} & Tanpa & 5,66 & 6,00 & 6,66 & $6,11 \mathrm{~b}$ \\
\hline & Gamal & 10,66 & 13,66 & 17,00 & $13,77 \mathrm{a}$ \\
\hline & Guano & 12,66 & 11,66 & 17,66 & $14,00 \mathrm{a}$ \\
\hline & Rerata & $9,66 \mathrm{~b}$ & $10,44 \mathrm{~b}$ & $13,77 \mathrm{a}$ & $(-)$ \\
\hline \multirow{4}{*}{3} & Tanpa & 11,66 & 13,33 & 15,00 & $13,33 \mathrm{~b}$ \\
\hline & Gamal & 18,33 & 20,33 & 22,33 & $20,33 \mathrm{a}$ \\
\hline & Guano & 18,66 & 18,00 & 24,00 & $20,22 \mathrm{a}$ \\
\hline & Rerata & $16,22 \mathrm{~b}$ & $17,22 \mathrm{~b}$ & $20,44 \mathrm{a}$ & $(-)$ \\
\hline \multirow{4}{*}{4} & Tanpa & 8,33 & 11,00 & 10,66 & $10,00 \mathrm{~b}$ \\
\hline & Gamal & 12,66 & 13,66 & 14,66 & $13,66 \mathrm{a}$ \\
\hline & Guano & 13,33 & 12,66 & 15,33 & $13,77 \mathrm{a}$ \\
\hline & Rerata & $11,44 \mathrm{~b}$ & $12,44 \mathrm{a}$ & $13,55 \mathrm{a}$ & $(-)$ \\
\hline
\end{tabular}

Keterangan: Angka pada baris dan kolom diikuti huruf sama menunjukkan tidak berbeda pada tingkat nyata $(\alpha) 5 \%$ menurut uji DMRT. (-) tidak terjadi interaksi antar faktor

\section{Berat Buah Per Tanaman}

Hasil sidik ragam (Anova) menunjukkan tidak terjadi interaksi antara perlakuan penyemprotan teh kompos dan pemberian penutup tanah terhadap parameter pengamatan berat buah per tanaman pada panen pertama. Pemberian penutup tanah berpengaruh tidak nyata terhadap berat buah pertanaman namun perlakuan pemberian penutup tanah penuh menghasilkan berat buah pertanaman paling tinggi yang tidak berbeda nyata dengan aras perlakuan lainnya dari awal panen sampai akhir panen. Pemberian teh kompos berpengaruh nyata terhadap berat buah per tanaman dari awal panen sampai akhir panen. Pada saat panen pertama perlakuan pemberian teh kompos gamal menghasilkan berat buah cenderung lebih berat $(29,26 \mathrm{~g})$ tetapi tidak berbeda nyata dengan teh guano, penyemprotan teh kompos guano cenderung lebih berat $(34,64$ dan 40,58 serta 34,17$)$, pada panen kedua, ketiga dan keempat tetapi tidak berbeda nyata dengan teh gamal (Tabel 14).

\section{$\underline{\text { Tabel 14. BeratBuah Per Tanaman }}$}

\begin{tabular}{cccccc}
\hline \multirow{2}{*}{ Waktu Panen } & Bahan Teh & \multicolumn{3}{c}{ Media Tanam } & \\
\cline { 3 - 5 } & Kompos & $\begin{array}{c}\text { Tanpa } \\
\text { Tanah }\end{array}$ & $\begin{array}{c}\text { Penutup Tanah } \\
1 / 2\end{array}$ & $\begin{array}{c}\text { Penutup } \\
\text { Tanah } \\
\text { Penuh }\end{array}$ & Rerata \\
\hline \multirow{4}{*}{1} & Tanpa & 22,2 & 22,63 & 24,4 & $23,07 \mathrm{~b}$ \\
& Gamal & 28,58 & 28,24 & 30,96 & $29,26 \mathrm{a}$ \\
& Guano & 29,46 & 26,83 & 29,56 & $28,62 \mathrm{a}$ \\
\cline { 2 - 5 } & Rerata & $26,75 \mathrm{a}$ & $25,90 \mathrm{a}$ & $28,31 \mathrm{a}$ & $(-)$ \\
\hline \multirow{4}{*}{2} & Tanpa & 26,16 & 26,86 & 27,46 & $26,83 \mathrm{~b}$ \\
& Gamal & 31,3 & 34,36 & 37,66 & $34,44 \mathrm{a}$ \\
& Guano & 33,43 & 32,3 & 38,2 & $34,64 \mathrm{a}$ \\
\hline \multirow{4}{*}{3} & Rerata & $30,3 \mathrm{a}$ & $31,17 \mathrm{a}$ & $34,44 \mathrm{a}$ & $(-)$ \\
\hline & Tanpa & 32,56 & 33,68 & 35,26 & $33,83 \mathrm{~b}$ \\
& Gamal & 38,47 & 40,52 & 42,64 & $40,54 \mathrm{a}$ \\
& Guano & 38,97 & 38,41 & 44,37 & $40,58 \mathrm{a}$ \\
\cline { 2 - 5 } & Rerata & $36,67 \mathrm{a}$ & $37,53 \mathrm{a}$ & $40,76 \mathrm{a}$ & $(-)$ \\
\hline \multirow{3}{*}{4} & Tanpa & 28,93 & 31,10 & 31,04 & $30,36 \mathrm{~b}$ \\
& Gamal & 32,96 & 33,9 & 34,93 & $33,93 \mathrm{a}$ \\
& Guano & 33,65 & 33,28 & 35,57 & $34,17 \mathrm{a}$ \\
\cline { 2 - 5 } & Rerata & $31,85 \mathrm{a}$ & $32,76 \mathrm{a}$ & $33,85 \mathrm{a}$ & $(-)$ \\
\hline
\end{tabular}

Keterangan: Angka pada baris dan kolom diikuti huruf sama menunjukkan tidak berbeda pada tingkat nyata $(\alpha) 5 \%$ menurut uji DMRT. (-) tidak terjadi interaksi antar faktor.

\section{Jumlah Total Buah}

Hasil sidik ragam (Anova) menunjukkan tidak terjadi interaksi antara perlakuan penyemprotan teh kompos dan pemberian penutup tanah terhadap jumlah total buah. Aras perlakuan pemberian penutup tanah maupun aras perlakuan penyemprotan teh kompos berpengaruh tidak nyata terhadap jumlah total buah (Tabel 15)

\section{Berat Total Buah}

Hasil sidik ragam (Anova) menunjukkan tidak terjadi interaksi antara perlakuan penyemprotan teh kompos dan pemberian penutup tanah terhadap berat total buah. Aras perlakuan penutup tanah maupun aras perlakuan penyemprotan teh kompos berpengaruh tidak nyata terhadap berat total buah (Tabel 16).
Tabel 15. Jumlah Total Buah

\begin{tabular}{ccccc}
\hline \multirow{2}{*}{ Bahan Teh Kompos } & \multicolumn{4}{c}{ Media Tanam } \\
\cline { 2 - 4 } & Tanpa & $\begin{array}{c}\text { Penutup } \\
\text { Tanah } 1 / 2\end{array}$ & $\begin{array}{c}\text { Penutup Tanah } \\
\text { Penuh }\end{array}$ & Rerata \\
\hline Tanpa & 28,98 & 33,33 & 36,32 & $32,87 \mathrm{a}$ \\
Gamal & 49,65 & 54,9 & 64,32 & $56,29 \mathrm{a}$ \\
Guano & 51,98 & 48,32 & 65,65 & $55,31 \mathrm{a}$ \\
\hline Rerata & $43,53 \mathrm{a}$ & $45,51 \mathrm{a}$ & $55,43 \mathrm{a}$ & $(-)$ \\
\hline
\end{tabular}

Keterangan: Angka pada baris dan kolom diikuti huruf sama menunjukkan tidak berbeda pada tingkat nyata $(\alpha) 5 \%$ menurut uji DMRT. (-) tidak terjadi interaksi antar faktor.

\section{Tabel 16. Berat Total Buah}

\begin{tabular}{ccccc}
\hline \multirow{2}{*}{ Bahan Teh Kompos } & \multicolumn{3}{c}{ Media Tanam } & \multirow{2}{*}{ Rerata } \\
\cline { 2 - 4 } & Tanpa & $\begin{array}{c}\text { Penutup } \\
\text { Tanah } 1 / 2\end{array}$ & $\begin{array}{c}\text { Penutup } \\
\text { Tanah Penuh }\end{array}$ & \\
\hline Tanpa & 109,85 & 114,27 & 118,16 & $114,09 \mathrm{a}$ \\
Gamal & 128,38 & 137,22 & 146,21 & $137,27 \mathrm{a}$ \\
Guano & 135,52 & 130,85 & 147,72 & $138,03 \mathrm{a}$ \\
\hline Rerata & $124,58 \mathrm{a}$ & $127,44 \mathrm{a}$ & $137,36 \mathrm{a}$ & $(-)$ \\
\hline
\end{tabular}

Keterangan: Angka pada baris dan kolom diikuti huruf sama menunjukkan tidak berbeda pada tingkat nyata ( $\alpha$ ) 5\% menurut uji DMRT. (-) tidak terjadi interaksi antar faktor.

\subsection{Pembahasan}

Hasil penelitian menunjukkan bahwa dampak dari faktor perlakuan penyemprotan teh kompos gamal dan teh kompos guano dan pemberian penutup tanah luar media terhadap tanaman cabai rawit tidak memberikan interaksi pada parameter lingkungan yang diamati. Tanaman cabai rawit dengan penyemprotan teh kompos dan pemberian penutup tanah dalam penelitian ini tidak memberikan pengaruh nyata terhadap kondisi lingkungan. Rata-rata pengaruh utama pemberian teh kompos guano dan pemberian penutup tanah penuh mengakibatkan kondisi lingkungan tanaman membaik seperti, kadar lengas meningkat dan ph tanah netral. Demikian pula pengaruh utama pemberian penutup tanah tidak menunjukkan beda nyata antar level perlakuan, namun pemberian penutup tanah mengakibatkan kondisi lingkungan tanaman, kadar lengas meningkat, $\mathrm{pH}$ mendekati netral dibandingkan dengan tanpa pemberian penutup tanah. Suhu tanah tidak menunjukan beda yang nyata antar perlakuan. Namun kondisi lingkungan yang berfluktuasi dalam penelitian ini sehingga suhu tanah berkisar antara $24-26^{\circ} \mathrm{C}$. Kondisi lingkungan tersebut berdampak pada pertumbuhan tanaman, hasil penelitian menunjukan bahwa dampak dari faktor perlakuan penyemprotan teh kompos dan pemberian penutup tanah terhadap tanaman cabai rawit tidak memberikan interaksi pada parameter pertumbuhan yang diamati pengaruh utama pemberian teh kompos guano menunjukan pertumbuhan tertinggi, diameter batang terbesar, berat kering tanaman terberat dan jumlah daun terbanyak dibandingkan perlakuan lainnya.

Hasil tanaman cabai rawit dalam penelitian ini tidak menunjukkan interaksi antar faktor perlakuan. Hasil penelitian menunjukkan bahwa parameter yang diamati cabai rawit untuk mendapatkan hasil terbaik pada perlakuan penyemprotan teh kompos guano, penyemprotan teh kompos gamal dan pemberian penutup tanah penuh yang ditunjukan pada parameter jumlah buah pertanaman terberat, jumlah buah pertanaman terbanyak, dan berat brangkasan terberat dibandingkan dengan tanaman cabai rawit yang diberi level perlakuan lainnya.

\section{Simpulan}

Berdasarkan hasil analisis dan pembahasan penelitian ini maka dapat disimpulkan bahwa tidak terjadi interaksi antara perlakuan modifikasi media tanam arang sekam dan pemberian teh kompos, hasil penelitian juga menunjukkan bahwa kadar lengas tertinggi dan $\mathrm{pH}$ tanah netral, pertumbuhan tinggi tanaman tertinggi, diameter batang terbesar, berat kering tanaman terberat, jumlah buah pertanaman terbanyak, berat buah terberat, dan berat kering tanaman terberat diperoleh dari aras perlakuan teh kompos guano maupun aras perlakuan penutup tanah penuh.

\section{Pustaka}

Barus A. 2008. Agroteknologi Tanaman buah-buahan. Medan USU-Press. Anwar, Muhammad Faisal. 2018. Pengaruh Bohasi Sampah Pasar dan Jenis Media Tanam terhadap Pertumbuhan Tanaman Selada Merah (red lettuce 1.) Varietas New Red Fire. Program Studi Agroteknologi Fakultas Sains Dan Teknologi Universitas Islam Negeri Sunan Gunung Djati Bandung.Http://digilib.uinsgd.ac.id/

Badan Pusat Statistik. (BPS) 2015.Kebutuhun Cabai Rawit di Indonesia. Badan Pusat Statistik. Available at www.bps .go.id

Gomez, K. A. Dan A.A Gomes. 1995. Prosedur Statitik untuk Penelitian Pertanian Edisi ke 2 Jakarta (Indonesia): UI Press

Ikpeme, C. E., Henry, P., \& Okiri, O. A. (2014). Comparative evaluation of the nutritional, phytochemical and microbiological quality of three pepper varieties. Journal of Food and Nutrition Sciences, 2(3), 74 https://doi.org/10.11648/j.jfns.201 40203.15

Kouassi CK, Koffi-nevry R, Guillaume LY et al. 2012. Profiles of bioactive compounds of some pepper fruit (Capsicum L.) Varieties grown in Côte d'ivoire. Innovative Romanian Food Biotechnol 11: 2331 . 
Pant, N., Fuloria, P. \& Tewari, B.C. A new well behaved exact solution in general relativity for perfect fluid. Astrophys Space Sci 340, 407412 (2012).https://doi.org/10.1007/s10509-012-1068-8

Scheuerell, S, and W Mahaffee. 2002. Compost tea: principles and prospects for plant disease control. Compost Science and Utilization. 10: 313 338

Setiadi. 2000. Bertanam Cabai. Penebar Swadaya. Jakarta.

Sharma, S., 2008, Topical Drug Delivery System : a Review, Pharmaceut. Rev., 6,129

St. Martin, CCG, and RAI Brathwaite. 2012. Compost and compost tea: principles and prospects as substrates and soil-borne disease management strategies in soil-less vegetable production. Biol. Agric. Hortic. 28:1-33. 